\title{
Irrational Beliefs in Romantic Relationships as the Predictor of Aggression in Emerging Adulthood*
}

\author{
Rezzan Gündoğdu ${ }^{1}$, Yasemin Yavuzer², Zeynep Karataş ${ }^{3}$ \\ ${ }^{1}$ Faculty of Education, Educational Science Department, Aksaray University, Aksaray, Turkey \\ ${ }^{2}$ Faculty of Education, Educational Science Department, Ömer Halisdemir University, Niğde, Turkey \\ ${ }^{3}$ Faculty of Education, Educational Science Department, Mehmet Akif Ersoy University, Burdur, Turkey \\ Correspondence: Rezzan Gündoğdu, Faculty of Education, Educational Science Department, Aksaray University, \\ Aksaray, Turkey.
}

Received: December 25, 2017

Accepted: February 6, $2018 \quad$ Online Published: February 22, 2018

doi:10.11114/jets.v6i3.2884

URL: https://doi.org/10.11114/jets.v6i3.2884

\begin{abstract}
The purpose of this study is to examine irrational beliefs in romantic relationships as the predictor of aggression in emerging adults. The study is a quantitative study done using the relational survey model. The study group is composed of 351 fourth-year students, 201 females and 150 males, who were attending three universities in Central Anatolia during the 2016-2017 academic year. In order to collect the study data, 23-item "KAR-YA Aggression Scale with four sub-dimensions (Physical Aggression, Hostility, Anger, Verbal Aggression) was used. 30-item "Irrational Romantic Relationship Beliefs Inventory" with six dimensions (Over Expectations, Use of Social Time, Mind Reading, Different Thinking, Physical Intimacy, Gender Differences) was used to determine the irrational beliefs in romantic relationships. Also, "Personal Information Form" was used to obtain the participants' personal and socio-economic information. The data collected was analyzed using the SPSS 18 package program. T-test analysis was conducted to find the correlation and the gender differences between aggression and irrational beliefs in romantic relationships, and multi-hierarchical regression analysis was conducted to determine whether irrational beliefs in romantic relationships predict aggression or not. When the study findings are examined, it is seen that males' aggression levels and their irrational expectation regarding the social and free time activities are higher. In addition, in explaining emerging adults' aggression sex is a significant predictor of different thinking and gender differences variables from the IRBI sub-dimensions.
\end{abstract}

Keywords: aggression, irrational beliefs in romantic relationships, emerging adulthood

\section{Introduction}

One of the important concepts that humankind try to understand and deal with, is aggression which is defined as one's harmful and destructive behaviors towards oneself, other individuals or objects. The explanation of the concept of aggression includes biological and social theories. The debate over which one comes first is considered a part of the nature-nurture debate. According to biological approaches, aggression is an innate and instinctive behavior. In other words, aggression is caused by a genetically programmed innate instinct looking for ways of release and waiting for an appropriate situation to reveal itself. According to social theories, aggression is defined as an impulse caused by social and situations; it can be from birth or it can be learned (Hogo \& Vaughan, 2006).

Just like aggression can be encountered in every situation in life, it can also be encountered in romantic relationships. As seen in the literature, many feelings like anger, guilt, fear, sadness and disappointment spring in conflict situations in romantic relationships (Sanford, 2007, p.66). As a destructive conflict resolution behavior, behaviors like verbal and physical abuse, relational aggression, threats and avoidance (Wolfe \& Scott, 2001, p.291) as well as behaviors like getting angry, attack, rapid breathing, withdrawal, using ways of isolation or denial and avoidance of dealing with problems emerge (Fieldman \& Kris, 1998, p.691). According to Saltzman, Fanslow, McMahon and Shelley (2002, p.11-13), aggression-violence in romantic relationships includes certain behaviors: (i) physical violence that

\footnotetext{
${ }^{*}$ II. ${ }^{\text {th }}$ International Academic Research Congress (INES). 18-21 October 2017. It was presented as a verbal statement at Antalya, Turkey.
} 
intentionally uses physical force like slapping, pushing, shaking, burning, poking, pulling hair or using weapon and may result in death or injury; (ii) sexual violence like physically forcing, having nonconsensual intercourse or abusing sexual intimacy; (iii) psychological/emotional violence like humiliation, control, hiding information, restricting communication with social environment, dragging the other to illegal activities and damaging the other's private's life or belongings. According to 2008 data of Centers for Disease Control and Prevention (CDC), about 25\% of adolescents are subjected to physical, psychological and sexual violence every year (Makin-Byrd \& Bierman, 2013). According to the World Health organization report, 35\% of women around the world are subjected to physical or sexual violence from their partners in their intimate relationship (WHO, 2017). In their study, Mason, Campbell, Zaharakis, Foster and Richards (2014) put forth that $26.1 \%$ of adolescents are exposed to psychological violence and $11.9 \%$ of them to physical violence in their ongoing relationships. A study conducted with Portuguese university students aged 18-23 found that many adolescents were harassed at least once in the last year by their female or male partners (Martins et al., 2014).

Lasting from ages 18 to 25 , emerging adulthood is a life stage theoretically and empirically different than adolescence and adulthood where the individual is neither an adolescent nor an adult and feels in-between (Arnett, 2000). This stage is a transitional time between adolescence and adulthood when the person feels in-between. An important characteristic of emerging adulthood is that it is the life period with the best opportunities for identity studies on love, job and world views (Arnett, 2000). The identity exploration process that occurs during this period motivates emerging adults to be in close interactions with others (Arnett, 2000). It is a period in which young men and women who want to establish close relationships can emotionally grow mature (Burger, 2006). Murray discusses the need for being close to others, cooperating with them, commitment and being loyal which he named "intimacy". One of the forms of relationships established with other individuals is a romantic relationship (Hendrick, 2009). Romantic relationships are one of the important relationships that meet the need for closeness. According to Sternberg $(1986,1997)$, romantic relationships are relationships between couples that are established by free choices and has elements of desire, commitment and closeness in them. Activities that have been at an earlier age in the past, such as marriage, having children and taking responsibility for a home, have now shifted to the late 20s. Romantic relationships are quite important for emerging adults who have been experimenting on many different subjects during this period because they are the relationships that they make their identity explorations on love. Therefore, formation and maintenance of romantic relationships during this period has critical significance (Eryllmaz \& Ercan, 2011; Fincham \& Cui, 2011). People's need to establish relationships and form emotional ties with other individuals are influenced by affective and cognitive processes (Hendrick, 2009). Beliefs about relationships are important while beginning a romantic relationship and also during the relationship. If the couples' beliefs are realistic and rational, the relationship may progress. When the beliefs about relationships are not realistic and rational, the couples are more likely to have problems in their relationships (Friedman \& Whisman, 1998). Irrational relationship beliefs are defined as individuals' exaggerated, rigid, unreasonable and change-resistant beliefs about the nature of the relationship, oneself and others (Ellis, 1986). Romans and DeBord (1995) expressed that couples with irrational beliefs expect to change each other's personalities (cited in Saraç, Hamamcı \& Güçray, 2015). On the other hand, rational and functional thinking style causes the individual to adapt better to the relationship (Metts \& Cupach, 1990). When the literature is examined, a few studies examining the irrational beliefs in romantic relationships in emerging adulthood were found. In these studies, it was put forth that people who are in romantic relationships have more nonfunctional beliefs compared to people who are not in romantic relationships (Gizir, 2013), having nonfunctional beliefs regarding being too close to others in relationships lead to negative results (Hamamc1, 2005a), and irrational beliefs differed between men and women (Sar1, 2008).

\subsection{The Objective of the Study}

Although there are many studies examining aggression in adolescence, only a few studies were conducted on aggression during the emerging adulthood period (for example, Camadan \& Yazici, 2017a; Çelikkaleli \& Tümtaş, 2017; Goldstein, 2011; Hasta \& Güler, 2013; Kurtyılmaz, 2011; Morsümbül, 2015). In these studies, self-esteem (Kurtyılmaz, 2011; Morsümbül, 2015), social exclusion (Çelikkaleli \& Tümtaş, 2017), perfectionism, forgiveness (Camadan \& Yazici, 2017a), attachment styles (Çelik, 2006), romantic relationships (Goldstein, 2011) and empathy (Hasta \& Güler, 2013) were found important predictors of aggression in emerging adulthood. Two studies examining the relationships between aggression and irrational beliefs in romantic relationships were found. One of these determined that university students' irrational beliefs about relationships are related to physical and emotional abuse (Kaygusuz, 2013). In their study conducted with males who showed aggression in their romantic relationships, Persampiere, Poole and Murphy (2014) determined that scientific distortions, illogical beliefs and the anger reaction are positively related with impulsivity. Hence, when couples' beliefs about romantic relationships not functional, it is considered that resolutions of conflicts in relationships will be difficult, unresolved problems will hurt the relationships and the couples, and thus aggression-violence tendencies will increase. The lack of studies on this thought and subject is the starting point of this study. It is, of course, believed that addressing variables that may be associated with aggression in emerging adulthood will support the problem's identification, prevention and control processes. The findings of this study can guide psycho-educational group works and 
individual and group psychological counseling works planned to reduce aggression in emerging adulthood, and help in setting objectives and determining measures to be taken. Thus, in this study, it was aimed to examine the irrational beliefs in romantic relationships as a predictor of aggression in emerging adults.

\section{Methodology}

Conducted to examine the irrational beliefs in romantic relationships as a predictor of aggression in emerging adults, this study is a quantitative study using relational survey model.

\subsection{Study Group}

Constituting the study group, participating emerging adults are fourth-year students who were attending three universities in Central Anatolia during the 2016-2017 academic year. Morsünbül (2015) stated that not everybody between the 19-26 age range in Turkey can be defined as emerging adult and that only the university students are included in the definition of emerging adulthood. Therefore, this study was conducted with university students. The participating university students were composed of 351 students, 201 females and 150 males. Their age range is between 18-28, and age mean is 21.09 .

\subsection{Data Collection Instrument}

KAR-YA Aggression Scale (KAR-YA AS): For the psychometric properties of KAR-YA Aggression Scale, which was developed by Karataş and Yavuzer (2016), item analysis, exploratory factor analysis, confirmatory factor analysis, criterion validity, internal consistency coefficient, split half test method and test retest method were used. Exploratory factor analysis showed that the scale had four factors, Physical Aggression (PA), Hostility (H), Anger (A) and Verbal Aggression (VA). The total score can be taken from the scale. The exploratory variance of the 23 -item scale ranged between 0.48 and 0.81 . Total exploratory variance of the four factors was $51.7 \%$. The scale's Cronbach alpha internal consistency coefficient for the total scale was calculated as 0.92 , split-half test reliability coefficient for both parts as 0.92 , and test retest reliability coefficient as 0.86. Confirmatory factor analysis results confirmed the four-factor structure of the scale (Karataş \& Yavuzer, 2016).

Irrational Relationship Beliefs Inventory (IRBI): For the psychometric properties of IRBI, developed by Sarı and Korkut Owen (2015), exploratory and confirmatory factor analysis, criterion validity and internal consistency coefficient were used. The exploratory variance showed that the scale had six factors, Over Expectations (OE), Use of Social Time (UST), Mind Reading (MR), Different Thinking (DT), Physical Intimacy (PI) and Gender Differences (GD). These six factors explained $51.70 \%$ of the total variance. OE explained $19.69 \%$ of the total variance, UST $10.10 \%$, MR $6.49 \%$, DT $5.71 \%$, PI 5.15, and GD 4.55\%. Calculated to determine internal consistency, Cronbach Alpha Coefficient was 0.85 for the total scale, and coefficients ranged between 0.53 and 0.81 for the sub-dimension. The correlation between IRBI and Irrational Beliefs Scale is 0.34, and 0.45 between IRBI and Scientific Distortions About Relationships Scale. Confirmatory factor analysis results confirmed the six-factor structure of the scale. Total score of the scale and the scale's sub-dimensions' scores can be taken separately. Over expectations sub-dimension is a dimension describing the unrealistic expectations one has from the relationship and the person they are in relation with. Use of Social Time sub-dimension is a dimension where unrealistic expectation statements about social and free time activities are put forth. Mind Reading sub-dimension is a dimension where unrealistic expectation statements are put forth about assuming what the other has in his or her mind without discussing each other's feelings and thoughts. Different Thinking sub-dimension includes unrealistic statements about how different thoughts are destructive. Physical Intimacy sub-dimension is on the unrealistic statements about physical intimacy. Gender Differences sub-dimension is a dimension where unrealistic statements are put forth about the effect of gender differences on the relationship (Sarı \& Korkut Owen, 2015).

\subsection{Data Collection and Analysis}

In this study, it was aimed to examine the irrational beliefs in romantic relationships as a predictor of aggression in emerging adults. The study is a quantitative study using relational survey model. The data collected was analyzed using the SPSS 18 package program. In data analysis, Pearson Product-Moment Correlation Coefficient was used to determine the relationship between aggression and irrational beliefs in romantic relationships, independent samples t-test to examine the difference in aggression in terms of gender, and multi-hierarchical regression analysis was to determine whether irrational beliefs in romantic relationships predict aggression or not. Before analyses, conformity of the data to normal distribution was tested by looking at its skewness and kurtosis values. Skewness values were between 1.21 and -0.42 , and kurtosis values were between 1.72 and -0.24 . Skewness and kurtosis values should ideally be between +1 and -1 but values between +2 and -2 are considered as acceptable (Karaatli, 2006). When testing autocorrelation, the Durbin-Watson coefficient was used. Durbin-Watson values varied between 1.64 and 1.88. Tolerance and VIF values were also within acceptable limits. In addition, as reported in the methodological literature, correlation coefficients between predictor variables that are 0.80 or above (Stevens, 2002, p. 93) indicate a multicollinearity problem. In this study, correlation coefficients between variables varied between 0.05 and 0.78 . 


\section{Findings}

\subsection{Findings Regarding Gender Differences}

Analysis results regarding the gender differences of aggression in emerging adulthood and irrational beliefs in romantic relationships are presented in Table 1.

Table 1. Findings regarding gender differences

\begin{tabular}{lllll}
\hline & Gender & \multirow{2}{*}{$\boldsymbol{t}_{(351)}$} & $\boldsymbol{p}$ \\
\cline { 2 - 4 } & Female & Male & -5.14 & 0.00 \\
\hline KAR-YA AS & $46.20 \pm 14.70$ & Mean \pm Sd & -8.99 & 0.00 \\
PA & $11.83 \pm 4.66$ & $55.66 \pm 14.76$ & -1.61 & 0.11 \\
H & $14.55 \pm 5.28$ & $17.25 \pm 5.27$ & -2.35 & 0.02 \\
A & $10.86 \pm 4.44$ & $15.61 \pm 5.38$ & -4.10 & 0.00 \\
VA & $8.95 \pm 3.24$ & $12.17 \pm 4.49$ & -0.11 & 0.91 \\
IRBI & $96.80 \pm 15.34$ & $10.61 \pm 3.25$ & 0.25 & 0.80 \\
OE & $29.70 \pm 6.04$ & $97.01 \pm 12.65$ & -1.90 & 0.06 \\
UST & $16.49 \pm 4.12$ & $29.52 \pm 4.94$ & 1.16 & 0.24 \\
MR & $20.30 \pm 4.51$ & $17.46 \pm 3.98$ & -1.28 & 0.20 \\
DT & $10.87 \pm 2.38$ & $19.95 \pm 4.15$ & 0.21 & 0.83 \\
PI & $9.92 \pm 2.78$ & $11.27 \pm 2.73$ & 0.88 & 0.38 \\
GD & $9.49 \pm 2.38$ & $9.85 \pm 2.45$ & $9.23 \pm 2.22$ & \\
\hline
\end{tabular}

Note: KAR-YA AS = KAR-YA Aggression Scale, PA=Physical Aggression, H=Hostility, A=Anger and VA=Verbal Aggression; IRBI= Irrational Relationship Beliefs Inventory, OE=Over Expectations, UST= Use of Social Time, MR= Mind Reading, DT= Different Thinking, PI= Physical Intimacy and GD= Gender Differences.

When Table 1 is examined, it is seen that there was a significant difference between female and male young adults' KAR-YA AS total scale scores and PA, A and VA sub-dimension scores. There was no significant difference between $\mathrm{H}$ sub-dimension scores. It was, also, found that while there was no significant difference between female and male young adults' IRBI total scores and OE, MR, DT, PI and GD sub-dimension scores, there was a significant difference between UST sub-dimension scores. According to these findings, it can be said that males' aggression levels and their unrealistic expectations about the social and free time activities (UST) were high.

\subsection{Findings Regarding Relationships Between Variables}

Correlation coefficients between aggression and irrational beliefs in romantic relationships in emerging adulthood and arithmetic mean and standard deviation values regarding the variables are presented in Table 2.

Table 2. Findings regarding relationship between variables

\begin{tabular}{|c|c|c|c|c|c|c|c|c|c|c|c|c|c|}
\hline Variables & Mean $\pm S d$ & KAR-YA AS & PA & $\mathbf{H}$ & $\mathbf{A}$ & VA & IRBI & OE & UST & MR & DT & PI & GD \\
\hline KAR-YA AS & $48.47 \pm 15.24$ & 1 & & & & & & & & & & & \\
\hline PA & $13.12 \pm 5.33$ & $0.84^{* *}$ & 1 & & & & & & & & & & \\
\hline $\mathbf{H}$ & $14.80 \pm 5.31$ & $0.78^{* *}$ & $0.46^{* *}$ & 1 & & & & & & & & & \\
\hline $\mathbf{A}$ & $11.18 \pm 4.48$ & $0.87^{* *}$ & $0.67^{* * *}$ & $0.54^{* *}$ & 1 & & & & & & & & \\
\hline VA & $9.35 \pm 3.32$ & $0.81^{* *}$ & $0.59^{* *}$ & $0.51^{* *}$ & $0.69^{* *}$ & 1 & & & & & & & \\
\hline IRBI & $96.85 \pm 14.73$ & $0.24^{* *}$ & $0.13^{*}$ & $0.32^{* *}$ & $0.14^{* *}$ & $0.18^{* *}$ & 1 & & & & & & \\
\hline $\mathbf{O E}$ & $29.66 \pm 5.79$ & 0.07 & 0.03 & $0.13^{*}$ & -0.00 & 0.06 & $0.78^{* *}$ & 1 & & & & & \\
\hline UST & $16.72 \pm 4.11$ & $0.21^{* *}$ & $0.16^{* *}$ & $0.24^{* *}$ & $0.14^{* *}$ & $0.13^{*}$ & $0.63^{* *}$ & $0.28^{* *}$ & 1 & & & & \\
\hline MR & $20.14 \pm 4.43$ & $0.19^{* *}$ & 0.09 & $0.26^{* *}$ & $0.11^{*}$ & $0.16^{* *}$ & $0.80^{* * *}$ & $0.61^{* *}$ & $0.27^{* *}$ & 1 & & & \\
\hline DT & $10.97 \pm 2.47$ & $0.28^{* *}$ & $0.14^{* *}$ & $0.33^{* *}$ & $0.26^{* *}$ & $0.20^{* *}$ & $0.47^{* *}$ & 0.07 & $0.33^{* *}$ & $0.32^{* *}$ & 1 & & \\
\hline PI & $9.91 \pm 2.70$ & 0.05 & -0.01 & $0.16^{* *}$ & -0.03 & 0.05 & $0.65^{* *}$ & $0.44^{* *}$ & $0.41^{\text {** }}$ & $0.37^{* *}$ & $0.26^{* *}$ & 1 & \\
\hline GD & $9.43 \pm 2.34$ & $0.24^{* *}$ & $0.15^{* *}$ & $0.26^{* *}$ & $0.20^{* *}$ & $0.18^{* *}$ & $0.49^{* *}$ & $0.23^{* *}$ & $0.19^{* * *}$ & $0.36^{* *}$ & $0.24^{* *}$ & $0.19^{* *}$ & 1 \\
\hline
\end{tabular}

p $<0.01,{ }^{*} \mathrm{p}<0.05$

Note: KAR-YA AS = KAR-YA Aggression Scale, PA=Physical Aggression, H=Hostility, A=Anger and VA=Verbal Aggression; IRBI= Irrational Relationship Beliefs Inventory, OE=Over Expectations, UST= Use of Social Time, MR= Mind Reading, DT= Different Thinking, PI= Physical Intimacy and GD= Gender Differences.

When Table 2 is examined, it is seen that there was a positive relationship between KAR-YA AS total score and IRBI total score $(\mathrm{r}=0.24)$, UST $(\mathrm{r}=0.21)$, MR $(\mathrm{r}=0.19)$, DT $(\mathrm{r}=0.28)$ and GD $(\mathrm{r}=0.24)$ sub-dimension scores. There was no significant relationship between KAR-YA AS and IRBI OE and PI sub-dimensions. A positive significant relationship between the scores of PA, a sub-dimension of KAR-YA AS, and IRBI total score ( $r=0.13)$, UST ( $r=0.16)$, DT ( $r=0.14)$, GD $(r=0.15)$ was found. There was no significant relationship between KAR-YA AS PA sub-dimension score and IRBI $\mathrm{OE}, \mathrm{MR}$ and PI sub-dimension scores. A positive significant relationship between the scores of $\mathrm{H}$, a sub-dimension of KAR-YA AS, and IRBI total score ( $r=0.32)$, UST $(r=0.24)$, MR $(r=0.26)$, DT $(r=0.33)$, PI $(r=0.16)$ and GD $(r=0.26)$ 
sub-dimension scores is seen. It is also seen that there is a positive significant relationship between the scores of A, a sub-dimension of KAR-YA AS, and IRBI total score $(r=0.14)$, UST $(r=0.14)$, MR $(r=0.11)$, DT $(r=0.26)$ and GD $(r=0.20)$ sub-dimension scores. There is no relationship between KARYA A sub-dimension score and IRBI OE and PI sub-dimension scores. It is also seen that there is a positive significant relationship between the scores of VA, a sub-dimension of KAR-YA AS, and IRBI total score ( $\mathrm{r}=0.18)$, UST $(\mathrm{r}=0.13)$, MR $(\mathrm{r}=0.16)$, DT $(\mathrm{r}=0.20)$ and GD $(\mathrm{r}=0.18)$ sub-dimension scores. A significant relationship between KAR-YA A sub-dimension score and IRBI OE and PI sub-dimension scores was not found.

\subsection{Results of Regression Analysis}

Whether irrational beliefs in romantic relationships predict aggression or not was examined with multi-hierarchical regression analysis. Since the aggression scores of female and male young adults differed, the gender variable was included in the regression analysis after redefining it as "dummy variable". In addition, the variables that would be included in the regression analysis were decided according to the findings given in Table 2 . The analysis results were presented in Table 3.

Table 3. Results of regression analysis

\begin{tabular}{|c|c|c|c|c|c|}
\hline Dependent variable & Independent variable & $R^{2}$ & $F$ & $\beta$ & $t$ \\
\hline \multirow{5}{*}{ KAR-YA AS } & Gender & \multirow{5}{*}{0.19} & \multirow{5}{*}{$16.04^{* *}$} & 0.26 & $5.26^{*}$ \\
\hline & UST & & & 0.07 & 1.31 \\
\hline & MR & & & 0.07 & 1.26 \\
\hline & DT & & & 0.18 & $3.31^{*}$ \\
\hline & GD & & & 0.17 & $3.30^{*}$ \\
\hline \multirow{4}{*}{ PA } & Gender & \multirow{4}{*}{0.23} & \multirow{4}{*}{$25.32^{* *}$} & 0.43 & $9.02^{*}$ \\
\hline & UST & & & 0.07 & 1.34 \\
\hline & DT & & & 0.05 & 0.97 \\
\hline & GD & & & 0.15 & $2.97^{* *}$ \\
\hline \multirow{7}{*}{$\mathbf{H}$} & Gender & \multirow{7}{*}{0.17} & \multirow{7}{*}{$10.15^{* *}$} & 0.08 & 1.51 \\
\hline & $\mathrm{OE}$ & & & -0.02 & -0.35 \\
\hline & UST & & & 0.10 & 1.79 \\
\hline & MR & & & 0.13 & 1.04 \\
\hline & DT & & & 0.22 & $3.87^{*}$ \\
\hline & PI & & & -0.01 & -0.10 \\
\hline & GD & & & 0.16 & $2.90^{* * *}$ \\
\hline \multirow{5}{*}{$\mathbf{A}$} & Gender & \multirow{5}{*}{0.10} & \multirow{5}{*}{$7.75^{* *}$} & 0.11 & $2.20^{* * *}$ \\
\hline & UST & & & 0.04 & 0.64 \\
\hline & MR & & & -0.01 & -0.16 \\
\hline & DT & & & 0.20 & $3.59^{*}$ \\
\hline & GD & & & 0.15 & $2.75^{* *}$ \\
\hline \multirow{5}{*}{ VA } & Gender & \multirow{5}{*}{0.11} & \multirow{5}{*}{$8.54^{* *}$} & 0.22 & $4.19^{*}$ \\
\hline & UST & & & 0.02 & 0.32 \\
\hline & MR & & & 0.09 & 1.50 \\
\hline & DT & & & 0.12 & $2.14^{* * * *}$ \\
\hline & GD & & & 0.13 & $2.34^{* * *}$ \\
\hline
\end{tabular}

p $<0.001, \stackrel{p}{\mathrm{p}}<0.01,{ }^{* * *} \mathrm{p}<0.05$

Note: KAR-YA AS = KAR-YA Aggression Scale, PA=Physical Aggression, H=Hostility, A=Anger and VA=Verbal Aggression; IRBI= Irrational Relationship Beliefs Inventory, OE=Over Expectations, UST= Use of Social Time, MR= Mind Reading, DT= Different Thinking, PI= Physical Intimacy and GD= Gender Differences.

When Table 3 is examined, it is seen that three variables (gender, IRBI's different thinking and gender differences sub-dimensions) are the significant predictors in explaining the levels of aggression in emerging adulthood (AS total score). When the findings are examined, it is also seen that scores of different thinking and gender differences, sub-dimensions of IRBI, explain the $19 \%$ of the total variance. Gender and IRBI's gender differences sub-dimension, which are the significant predictors in explaining levels of physical aggression in emerging adults, explain $23 \%$ of the total variance. According to Table 3, IRBI's different thinking and gender differences sub-dimensions are significant predictors in explaining the levels of hostility in emerging adults, and together they explain $17 \%$ of the total variance. It is seen that gender, IRBI's different thinking and gender differences sub-dimensions are significant predictors in explaining the levels of anger and verbal aggression in emerging adults, and together they explain $17 \%$ of the total variance. These variables together explain $10 \%$ of the anger total variance and $11 \%$ of the verbal total variance.

\section{Discussion, Conclusion and Recommendations}

In the study, it was aimed to examine the extent irrational beliefs in romantic relationships predict aggression in emerging adults. One of the study findings is that the aggression levels of males are high. Studies conducted on 
aggression in emerging adulthood both in Turkey and abroad show that males' aggression levels are high (for example, Camadan \& Yazıc1, 2017b; Goldstein, 2011; Hasta \& Güler, 2013; Johnson, Giordano, Manning \& Longmore, 2015). This result, obtained in the study, can be explained by the social roles loaded on men and women. The reason why males' aggression levels are higher than females' aggression levels can be due to the fact that boys, during socialization, are taught to be courageous, bold and proud of their masculinity because of the patriarchal Turkish society, girls are taught to be cowardly, shy and passive. Boys' aggressive behaviors are being supported, aggression is considered a sign of masculinity and the fact that there are more social sanctions for girls' aggressive behaviors (Atay, 2004: 11 cited in Yavuzer, Karataş \& Gündoğdu, 2013). It was also found that males' unrealistic expectations about the social and free time activities, one of the irrational beliefs of emerging adults in romantic relationships are higher than females' unrealistic expectations. Previous study findings also revealed that irrational beliefs about romantic relationships differ according to gender. In Sarı (2008)'s study, females' over expectations and physical intimacy sub-dimension scores are higher than males' scores, and their use of social time and different thinking sub-dimension scores are lower than males' scores. Gizir (2013) determined that compared to female students, male students scored higher in "We should do everything together", "We should meet each other's needs" and "we should be able to change each other" beliefs, which are among the beliefs regarding romantic relationships. In studies conducted on romantic relationships, gender was one of the most researched variables. It is known that the majority of the differences between men and women in societies spring from gender roles (Winstead \& Derlaga, 1993). In this context, it can be said that men in their emerging adulthood period consider themselves as a character who is strong and dominant. As a result of the analysis done, it is seen that gender and IRBI's different thinking and gender differences sub-dimensions are significant predictors in explaining levels of aggression (AS PA, H, A, VA) in emerging adults. IRBI Different Thinking sub-dimension consists of unrealistic statements about how different thoughts are destructive. Some of these include statements like "I cannot bear it if the person I am with discusses their opposite views with me" and "If we do not think the same way about events, it would be meaningless to continue the relationship". IRBI Gender Differences sub-dimension consists of unrealistic statements about the effect of gender differences on the relationship. Some of these include statements like "Women and men probably will never understand the opposite sex enough" and "Biological differences between women and men are the main reason behind the couples 'problems". Beliefs about relationships consist of individuals' thoughts about how a relationship should be, their expectations from relationships and the way they perceive events (Addis \& Bernard, 2002). When beliefs are rigid, unreasonable and resistant to change, the couples will inevitably experience problems in their relationships. As irrational beliefs increase, disagreements and frustrations arise among couples, and this can lead to conflicts and break-ups in romantic relationships (Addis \& Bernard, 2002; Hamamc1, 2015b). Therefore, according to findings of this study, the inability to tolerate conflicts, and men and women believing that they are emotionally and biologically are different may negatively affect couples' communication and may lead to problems in their romantic relationships. These problems may also cause aggressive and violent behaviors. In previous studies, it was found that individuals with this type of irrational beliefs experience more communication conflicts in their romantic relationships and communicate more negatively (Reed \& Dubow, 1997). Gizir (2013) determined that emerging adults' irrational beliefs in their romantic relationships are associated with physical and emotional abuse.

Consequently, thinking differently and having irrational beliefs about gender differences in romantic relationships is associated with aggression in emerging adulthood, and are significant predictors of physical aggression, verbal aggression, hostility and anger, which are the types of aggression. These findings show that psychological counselors working particularly with young people who have aggression problems should focus on irrational beliefs in romantic relationships. This study has some limitations. The data was collected through emerging adults' self-assessments. Therefore, the participants' responses that were given through marking the items in the scale may not be similar to their real life behaviors. Another limitation is that participants were not asked whether they were involved in a romantic relationship or not. Future studies may examine emerging adults who are in romantic relationships or who flirt or who are engaged, and the relationship between aggression and the state of being in a romantic relationship may be investigated. In addition, models about examining variables (loneliness, adult attachment styles, self-concept, etc.) affecting aggression in emerging adulthood may be developed.

\section{References}

Addis, J., \& Bernard, M. E. (2002). Marital adjustment and irrational beliefs. Journal of Rational Emotive and Cognitive Behavioral Therapy, 20, 3-13. https://doi.org/10.1023/A:1015199803099

Arnett, J. J. (2000). Emerging adulthood: A theory of development from the late teens through the twenties. American Psychologist, 55, 469-480. https://doi.org/10.1037/0003-066X.55.5.469

Atay, T. (2004). Erkeklik en çok erkeği ezer. Toplum ve Bilim, 101, 11-30.

Burger, J. M. (2006). Kişilik. (Çev. Sarıŏlu, E.D.İ.), İstanbul: Kaknüs Yayınları. 
Camadan, F., \& Yazıc1, H. (2017a). A model to aggression in university students. H. U. Journal of Education, 32(2), 343-360.

Camadan, F., \& Yazıcı, H. (2017b). Üniversite öğrencilerinde gözlenen saldırganlık eğilimlerinin çeşitli değişkenler açısından incelenmesi. Yüksekögrretim ve Bilim Dergisi, 7(2), 225-234.

Çelik, H. (2006). Üniversite birinci sınıf öğrencilerinin saldırganlık tepkileri, bağlanma tarzları ve kişilerarası şemalarının incelenmesi (Yayımlanmamış yüksek lisans tezi). Marmara Üniversitesi, Eğitim Bilimleri Enstitüsü, İstanbul.

Çelikkaleli, Ö., \& Tümtaş, M. S. (2017). Mediation role of social alienation in the relationship between exclusions and aggression in university students. Journal of Mehmet Akif Ersoy University Education Faculty, 43, 155-175.

Ellis, A. (1986). Rational emotive therapy applied to relationships therapy. Journal of Rational Emotive Behavior Therapy, 4, 14-21. https://doi.org/10.1007/BF01073477

Eryılmaz, A., \& Ercan, L. (2011). Beliren yetişkinlikte romantik yakınlığı başlatma ve algılanan kontrol. Gazi Eğitim Fakültesi Dergisi, 31(2), 359-380.

Fieldman, S. S., \& Kris, G. L. (1998). Conflict negotiation tactics in romantic relationships in high school students. Journal of Youth and Adolescence, 27(6), 691-717. https://doi.org/10.1023/A:1022857731497

Fincham, F. D., \& Cui, M. (2011). Emerging adulthood and romantic relationships an introduction. In Romantic Relationships in Emerging Adulthood. (Eds. F. D. Fincham and M. Cui) New York: Cambridge University Press, 3-12.

Friedman, M. A., \& Whisman, M. A. (1998). Interpersonal problem behaviors associated with dysfunctional attitudes. Cognitive Therapy \& Research, 98(22), 149-160.

Gizir, C. A. (2013). Üniversite öğrencilerinin ilişki inançlarının cinsiyet ve romantik ilişki yaşama durumlarına göre incelenmesi. Eğitim ve Bilim, 38(170), 372-383.

Goldstein, S. E. (2011). Relational aggression in young adults' friendships and romantic relationships. Personal Relationships, 18, 645-656. https://doi.org/10.1111/j.1475-6811.2010.01329.x

Hamamc1, Z. (2015a). Dysfunctional relationship beliefs in marital satisfaction and adjustment. Social Behavior and Pesonality, 33(4), 313-328. https://doi.org/10.2224/sbp.2005.33.4.313

Hamamc1, Z. (2015b). Dysfunctional relationship beliefs in marital conflict. Journal of Rational-Emotive \& Cognitive-Behavior Therapy, 23(3), 245-261. https://doi.org/10.1007/s10942-005-0013-y

Hasta, D., \& Güler, M. E. (2013). Saldırganlık: Kişilerarası ilişki tarzları ve empati açısından bir inceleme. Ankara Üniversitesi Sosyal Bilimler Enstitüsü Dergisi, 4(1), 64-104. https://doi.org/10.1501/sbeder_0000000051

Hendrick, S. S. (2009). Yakın ilişkiler psikolojisi. (Çev. Ed. A. Dönmez). Ankara: Nobel Yayınevi.

Hogo, M. A., \& Vaughan, G. M. (2006). Sosyal psikoloji. (Çev. İbrahim Yıldız, Aydın Gelmez). Ankara: Ütopya Yayınları.

Johnson, W. L., Giordano, P. C., Manning, W. D., \& Longmore, M. A. (2015). The age IPV curve: Changes in the perpetration of intimate partner violence during adolescence and young adulthood. Journal of Youth Adolescence, 44, 708-726. https://doi.org/10.1007/s10964-014-0158-z

Karaatli, M. (2006). Regulation and representation of the data: In Kalaycioglu S (editor). SPSS Applied Multivariate Statistical Techniques. Second Edition, Ankara: Asil Publication Distribution, 3-47.

Karataş, Z., \& Yavuzer, Y. (2016). Lise ve üniversite öğrencileri için Kar-Ya saldırganlık ölçeği geliştirilmesi ve psikometrik özelliklerinin incelenmesi. Mehmet Akif Ersoy Üniversitesi Sosyal Bilimler Enstitüsü Dergisi, 8(17), 307-321.

Kaygusuz, C. (2013). Irrational beliefs anda buse in university students' romantic relations. Eurasian Journal of Educational Research, 51, 141-156.

Kurtyılmaz, Y. (2011). Üniversite öğrencilerinin iliş̧kisel saldırganlık ile benlik saygısı sosyal bağglllk ve sosyal kaygl düzeyleri arasındaki ilişkiler. Yayımlanmamış Doktora Tezi, Anadolu Üniversitesi, Eğitim Bilimleri Enstitüsü, Eskişehir.

Laursen, B., \& Collins, W. A. (1994). Interpersonal conflict during adolescence. Psychological Bulletin, 115, 197-209. https://doi.org/10.1037/0033-2909.115.2.197

Makin-Byrd, K., \& Bierman, K. L. (2013). The Conduct Problems Prevention Research Group. (2013). Individual and Family Predictors of The Perpetration of Dating Violance and Victimization in Late. Adolescence. Journal of Youth 
Adolescence, 42(4), 536-550. https://doi.org/10.1007/s10964-012-9810-7

Martins, C., Gouveia, A., Chaves, M., Lourenço, R., Marques, S., \& Santos, T. (2014). Dating violance and nursing student well-being. Atencion Primaria, 46(1), 129-134. https://doi.org/10.1016/S0212-6567(14)70079-4

Mason, M. J., Campbell, L., Zaharakis, N., Foster, R., \& Richards, S. (2014). Levels of teen dating violence and substance use in an urban emergency department. Journal of Developmental \& Behavioral Pediatrics, 35(9), 576-581. https://doi.org/10.1097/DBP.0000000000000095

Metts, S., \& Cupach, W. R. (1990). The influence of relationship beliefs and problem solving responses on satisfaction in romantic relationships. Human Communication Research, 17(1), 170-185. https://doi.org/10.1111/j.1468-2958.1990.tb00230.x

Morsünbül, Ü. (2015). The effect of identity development, self-esteem, low self-control and gender on aggression in adolescence and emerging adulthood. Eurasian Journal of Educational Research, 61, 99-116. https://doi.org/10.14689/ejer.2015.61.6

Persanpiere, J., Poole, G., \& Murphy, C. M. (2014). Neuropsychological correlates of anger, hostility, and relationship-relevant distortions in thinking among partner violent men. Journal of Familiy Violence, 29, 625-641. https://doi.org/10.1007/s10896-014-9614-5

Reed, J. S., \& Dubow, E. F. (1997). Cognititve and behavioral predictors of communication in clinic-referred and non-clinical mother-adolescent dyads. Journal of Marriage and the Family, 59, 91-102. https://doi.org/10.2307/353664

Saltzman, L., Fanslow, J. L., McMahon, P. M., \& Shelley, G. A. (2002). Intimate partner violence surveillance uniform definitions and recommended data elements,version 1.0. Atlanta (GA): Centers for Disease Control and Prevention National Center for Injury Prevention and Control Atlanta, Georgia.

Sanford, K. (2007). Hard and soft emotion during conflict: Investigating married couples and other relationships. Personal Relationships, 14, 65-90. https://doi.org/10.1111/j.1475-6811.2006.00142.x

Saraç, A., Hamamcı, Z., \& Güçray, S. (2015). Üniversite öğrencilerinin romantik ilişki doyumunun yordanması. Türk Psikolojik Danışma ve Rehberlik Dergisi, 5(43), 69-81.

Sarı, T. (2008). Üniversite öğrencilerinde romantik ilişkilerle ilgili akılcı olmayan inançlar, bağlanma boyutları ve ilişki doyumu arasındaki ilişkiler. Yayınlanmamış Doktora Tezi. Sosyal Bilimler Enstitüsü, Hacettepe Üniversitesi, Ankara.

Sarı, T., \& Korkut-Owen, F. (2015). Romantik ilişkilerde akılcı olmayan inançlar ölçeği’nin geliştirilmesi. International Journal of Human Sciences, 12(1), 255-273. https://doi.org/10.14687/ijhs.v12i1.3068

Sternberg, J. R. (1986). A triangular theory of love. Psychological Review. 93, 119-135. https://doi.org/10.1037/0033-295X.93.2.119

Sternberg, J. R. (1997). Construct validation of a triangular love scale. European Journal of Social Psychology, 27, 313-335. https://doi.org/10.1002/(SICI)1099-0992(199705)27:3<313::AID-EJSP824>3.0.CO;2-4

Stevens, J. P. (2002). Applied multivariate statistics for the social sciences. Fourth Edition. Mahwah, New Jersey: Lawrence Erlbaum Associates, Publishers.

WHO (2017). http://www.who.int/mediacentre/factsheets/fs239/en/

Winstead, B. A., \& Derlega, V. J. (1993). Gender and Close Relationships: An introduction . Journal of Social Issues , 49(3), 1-9. https://doi.org/10.1111/j.1540-4560.1993.tb01165.x

Wolfe, D., \& Scott, C. (2001). Child maltreatment: risk of adjustment problems anddating violence in adolescence. Journal of the American Academy of Child \& Adolescant Psychiatry, 40(3), 282-289. https://doi.org/10.1097/00004583-200103000-00007

Yavuzer, Y., Karataş, Z., \& Gündoğdu, R. (2013). An İnvestigation of conflict resolution behaviours: a quantitative and qualitative study. H. U. Journal of Education, 28(1), 428-440.

\section{Copyrights}

Copyright for this article is retained by the author(s), with first publication rights granted to the journal.

This is an open-access article distributed under the terms and conditions of the Creative Commons Attribution license which permits unrestricted use, distribution, and reproduction in any medium, provided the original work is properly cited. 